\title{
Between Minimum Force and Maximum Violence: Combating Political Violence Movements with Third-Force Options
}

\author{
Doron Zimmermann *
}

\section{Introduction: Balancing the Tools of Counter-Terrorism}

In most liberal democratic states it is the responsibility of the police forces to cope with "internal" threats, including terrorism, since in such states terrorism is invariably defined as a criminal act rather than a manifestation of insurgent political violence. In many such instances, the resultant quantitative and qualitative overtaxing of law enforcement capabilities to keep the peace has led to calls by sections of the public, as well as by the legislative and executive branches of government, to expand both the legal and operational means available to combat terrorism, and to boost civilian agencies' capacity to deal with terrorism in proportion to the perceived threat. The deteriorating situation in Ulster in Northern Ireland between 1968 and 1972 and beyond is an illustrative case in point. ${ }^{1}$

Although there have been cases of successfully transmogrifying police forces into military-like formations, the best-known and arguably most frequent example of augmented state responses to the threat posed by insurgent political violence movements is the use of the military in the fight against terrorism and in the maintenance of internal security. While it is imperative that the threat of a collapse of national cohesion due to the overextension of internal civil security forces be averted, the deployment of all branches of the armed forces against a terrorist threat is not without its own pitfalls. Paul Wilkinson has enunciated some of the problems posed by the use of counter-terrorism military task forces, not the least of which is that

[a] fully militarized response implies the complete suspension of the civilian legal system and its replacement by martial law, summary punishments, the imposition of curfews, military censorship and extensive infringements of normal civil liberties in the name of the exigencies of war. ... the government finds it has removed all the constraints of legal accountability and minimum force, enabling the military commanders to deploy massively lethal and destructive firepower in the name of suppressing terrorism. ${ }^{2}$

* Doron Zimmermann is Senior Researcher with the Center for Security Studies at the Swiss Federal Institute of Technology (ETH), where he heads a university-based research project on internal and international terrorism and also conducts applied policy research.

1 A good review of events from the perspective of the Irish Nationalist/Republican movement's perspective can be found in J. Bowyer Bell, The Secret Army: The IRA (New Brunswick, NJ: Transaction Publications, 1997).

2 Paul Wilkinson, Terrorism Versus Democracy. The Liberal State Response (London: Frank Cass, 2002), 103. 
Probably the most illustrative contemporary rendition of a situation that spirals out of control because the military has been called in to tackle the terrorist problem is Edward Zwick's 1998 motion picture The Siege. ${ }^{3}$ Provided one allows for artistic license, The Siege offers great insight into the nature of the subject: the point somewhat allegorically made in the film is that, when surgery is required, a sword is not the right instrument with which to perform the operation. At the end of the day, the question remains of what is to be done. If the first, democratically sound option (e.g., the police) is for a variety of reasons not equipped to deal with the problem, and the second, $u l$ tima ratio option (the military) may well defeat the purpose of the exercise due to its very nature - at the heart of which lies the use of maximum force - then maybe we need to seek a third option. A third option also implies a third force.

\section{Paramilitary Formations in Historical Context}

The debate concerning what a third-force capability should be is ongoing, but it has received added urgency due to recent events in international relations. Over the years, suggestions have ranged from militarizing the police to constabularizing the armed forces. More important, and as an extension to the logic of this debate, which may be summarized as a desire for the best of both worlds, the idea of paramilitaries - groups with some characteristics of both the police and the military-has at some stage also entered the discussion as a viable solution. ${ }^{4}$ To cut a long etymological (if not definitional) debate short, the term paramilitary came into use some six decades ago when British journalists used it to "describe Nazi-sponsored groups of enforcers that policed movement rallies and disrupted those of their opponents." Admittedly, paramilitaries combine both the inherent weaknesses and strengths of police and military forces. But it is precisely for this reason that paramilitaries not only pose a risk in the context of a proportional response to terrorism; they also offer the greatest potential for shaping up to be the long sought after, well-calibrated countermeasure to terrorism, in that they can best fulfill the requirements of the liberal democratic state. They arguably remain the best option to effectively combat terrorism that we have at present.

The critical issue beyond the immediate choice of means, however, is not exclusively one of finding an appropriate and balanced solution in the context of highly politicized civil-military relations alone, but one of guaranteeing proportionality to the threat. Even more to the point, it is a question of how to make the response capability both adequate and democratically controllable (and hence politically viable). In order to better discuss the subject of how best to respond to political violence and terrorism

3 Edward Zwick, dir., The Siege (Los Angeles: $20^{\text {th }}$ Century Fox, 1998). For more information on The Siege, visit the relevant entry in the Internet Movie Database (IMDb) at http://www.imdb.com/title/tt0133952/, accessed on 26 May 2004.

4 For a brief discussion on the nature of paramilitaries, see http://en.wikipedia.org/wiki/ Paramilitary, accessed on 5 May 2004.

5 Andrew Scobell and Brad Hammitt, "Goons, Gunmen, and Gendarmerie: Toward A Reconceptualization of Paramilitary Formations," Journal of Political and Military Sociology 26:2 (Winter 1998): 213-27; at 219. 
on the ground, we need to selectively investigate the historical background of thirdforce paramilitaries in order to achieve an organic understanding of the subject. This should be done with a view to assessing the utility of paramilitary units in the role of third-force counter-terrorist options.

\section{Antecedents in Antiquity and Early Modern History}

That the past has a way of shaping the present is a truism that applies to the combating of political violence. In search of a tool to effectively fight political violence and terrorism that would prove both operationally effective and, to a lesser extent, politically viable, a variety of approaches have been attempted through the centuries. Significantly, the antecedents of today's governmental paramilitary units must be sought in the age of antiquity rather than in the period after 1945, when such formations became better known. Then as now, insurgency and subversion were usually directed at either unpopular indigenous governments or against occupying powers in the wake of conquest. In the event that incumbent powers in the past were not willing to sacrifice the civilian population alongside the insurgents, means other than wholesale eradication or forced migration had to be found. One way of achieving a level of precision in rooting out political violence movements was the employment of allied local forces; they were usually given a supporting, auxiliary role in conventional war, as well as in counter-insurgency operations, in the pursuit of which they featured even more prominently.

Starting in the Roman Republic, the auxiliarii, who were tasked with border defense and whose principal role during and following campaigns was to assist the "regular" Roman military, were recruited from among subject peoples within Rome's power orbit. ${ }^{6}$ The employment of irregular troops in the role of supporting or specialized forces and their integration into regular army establishments created a precedent followed by another empire centuries later. In the course of suppressing the Jacobite rebellion of 1745-46 in Scotland, Lord Loudon's irregular Highland companies were formed and deployed with the express purpose of mopping up Jacobite pockets of resistance after the Battle of Culloden (16 April 1746), as well as with countering Jacobite clan guerilla attacks subsequent to the end of conventional military operations in the autumn of $1746 .^{7}$ The British Empire used the lessons learned in the course of eventually suppressing the intrepid Jacobite clans in the Scottish Highlands with devastating effect during the Seven Years' War (1756-1763), in the course of which irregulars fought on both sides of the conflict. ${ }^{8}$ Despite running the risk of committing a gross anachronism, it can be contended that the eighteenth century saw widespread

6 For further reference on the auxiliarii, see http://library.thinkquest.org/22866/English/ Leger.html?tqskip1=1, accessed on 26 May 2004.

7 Doron Zimmermann, The Jacobite Movement in Scotland and in Exile, 1746-1759 (Basingstoke: Macmillan/Palgrave, 2003); see especially the chapter entitled "Suppression and Resistance: Hanoverians and Jacobites in 1746-1747," 21-47.

8 For more on the uses of irregulars by the British army at home and abroad, see Peter E. Russell, "Redcoats in the Wilderness: British Officers and Irregular Warfare in Europe and America, 1740 to 1760," William and Mary Quarterly, Third Series, 35:4 (1978): 629-52. 
use - even the institutionalization - of irregular units with distinct paramilitary characteristics in regular armies, at least in the manner that we would understand the term today. ${ }^{9}$

\section{Paramilitaries in the Second World War and Cold War Periods}

The use of such irregular paramilitaries flowed and ebbed after the French Revolution, but the need for irregular, and increasingly specialized, groups did not disappear. As a matter of fact, quite the contrary is true. In the course of the Second World War, the so-called commandos of the British army-usually regular soldiers seconded to special units deployed far behind enemy lines - had an impact on the Allied war effort. As early as November 1941, an American officer visited Britain in order to evaluate the British commandos. In due course, the precursor to the CIA, the Office of Strategic Services (OSS), used similar units with great success in France, where they helped prop up the Maquis against the Nazi occupation, and in Norway, where small Allied paramilitary units wreaked havoc with German rail supply lines. Significantly, when the idea of using specialized troops struck home in the U.S. during the war, it was cast not in terms of regular military personnel being used in unorthodox ways, but rather in terms of drawing highly skilled human resources from regular military units for the purpose of redeploying them as combatants who were not members of the armed forces. Operatives in such paramilitary units were taught a variety of skills critical to classical independent, long-range reconnaissance missions, such as aerial and maritime insertion, demolitions, unarmed combat, sabotage, and managing the logistics of local resistance movements. ${ }^{10}$

In the context of the Second World War, however, paramilitaries also featured in one of this conflict's darkest chapters. Axis powers, especially the Nazi regime, adhered to the ideology of "blood and soil," and reveled in a cult of racialist purity and fascist-influenced, contrived virility. Inarguably most sinister incarnation of this mentality was a paramilitary unit known as the Schutzstaffel (SS), run by Heinrich Himmler, which acted as a separate, quasi-sovereign entity and operated according to its own rules within the Nazi state. The original purpose of the SS was to control all other Nazi governmental structures, including other paramilitaries (e.g., the Sturm Abteilung, or SA) and the regular military (the Wehrmacht). "Being a kind of party police both by precept and function, the raison d'etre of the SS was loyalty to the Führer."11

9 Ian F.W. Beckett, Modern Insurgencies and Counter-Insurgencies. Guerrillas and their Opponents since 1750 (London: Routledge, 2001), 2-5.

10 Major D.H. Berger, "The Use of Covert Paramilitary Activity as a Policy Tool: An Analysis of Operations Conducted by the United States Central Intelligence Agency, 1949-1951," (n.p.: 1995), 7-8; available at www.globalsecurity.org/intell/library/reports/1995/BDH.htm, accessed on 1 April 2004.

11 Gerhard Rempel, "Nazi Paramilitary Groups: SA and SS," 3; available at http://mars.acnet.wnec.edu/ grempel/courses/germany/lectures/26paramilitary.html, accessed on 19 May 2004. 
In contrast to the Allied paramilitaries and commandos, the SS, especially the Waffen-SS, had more in common with the original concept of the auxiliarii, in that they were frequently integrated into regular army corps and served as security assistance forces in combat operations in the front line of battle rather than behind enemy lines. Moreover, the praetorian function of acting "as a bulwark against overthrow by the ... Army" or any other competing government organization is one that has been replicated many times since, with paramilitary organizations frequently singled out to play a key role to this end. ${ }^{12}$ A more recent but no less notorious example of this type of praetorian paramilitary formation employed to control and intimidate rival government organizations and civil society alike is that of the notorious Haitian Tontons Macoutes.

After the erstwhile Allies of the Second World War became estranged from each other along an East-West divide in 1947, the U.S. and British governments were quick to realize the potential of paramilitary formations in both the maintenance of internal security - up to and including counterinsurgency assignments - in the face of Communist subversion and in special operations behind the descending Iron Curtain. The widespread endorsement of paramilitaries in the service of foreign policy during the Cold War helps explain the later proliferation of paramilitaries into other, derivative spheres of statecraft and policy, such as counter-terrorism.

The Truman Doctrine, which President Truman promulgated before the U.S. Congress in March 1947, promised beleaguered states assistance against Communist incursion. Coupled with the increasing need to avoid direct confrontation between the emerging superpowers, this doctrine also rapidly and emphatically introduced paramilitaries to the variegated battlefields of the Cold War. ${ }^{13}$ The immediate necessity for internal security assistance, as enunciated by Truman, was carried over into the next phase of the Cold War when, on 21 December 1954, U.S. President Dwight D. Eisenhower ordered a landmark undertaking known as NSC 1290-d. The express purpose of NSC 1290-d was to systematically "organize, train and equip local police and other internal security forces to combat Communist subversion in the underdeveloped countries." ${ }^{\text {"14 }}$ Confronted with comparable challenges, France and Britain also bent their efforts to the interdiction of subversive forces in Third World states whose regimes were on friendly terms with the West, especially in Southeast Asia. ${ }^{15}$ The use of paramilitary forces in a crucial role in internal security assistance was yet again endorsed in NSC Action Memorandum No. 162, which dealt with the "development of U.S. and Indigenous Police, Paramilitary and Military Resources.",16

12 Scobell and Hammitt, "Goons, Gunmen, and Gendarmerie," 214.

13 Andreas Wenger and Doron Zimmermann, International Relations. From the Cold War to the Globalized World (Boulder, CO: Lynne Rienner Publishers, 2003), 19.

14 William Rosenau, "The Eisenhower Administration, U.S. Foreign Internal Security Assistance, and the Struggle for the Developing World, 1954-1961," Low Intensity Conflict \& Law Enforcement 10:3 (Autumn 2001):1-32; cited passage at 12.

15 Ibid., 15.

16 NSC Action Memorandum No. 162 is available at www.mtholyoke.edu/acad/intrel/ pentagon2/doc116.htm, accessed on 17 May 2004. 
The CIA paramilitary program was enacted even before the U.S. government's internal security assistance program came to prominence in the $1950 \mathrm{~s}$. Throughout the Cold War and beyond, the CIA's investment in the use of paramilitaries in behind-thelines operations was considerable, reaching from Albania to Poland to Guatemala. Plans in the U.S government to use special operations paramilitaries came to fruition in 1948. Against the backdrop of the Soviet war scare, the CIA received a mandate from the U.S. National Security Council "broadening the scope of covert activity to include political, economic, and paramilitary operations," which also enshrined the key advantage of using paramilitaries for behind-the-lines operations: the concept of plausible deniability. ${ }^{17}$ This last point should also be borne in mind when considering counterterrorism operations under adverse conditions, or in hostile territory. Be that as it may, the list of countries that have seen CIA paramilitaries in action is long and continues to grow, with the most recent example being Afghanistan.

Paralleling the course of the U.S. paramilitary effort, the British army also developed a similar non-military capability. In contrast to the CIA program, however, the British experience with paramilitaries was short-lived. One reason for cutting short a promising British paramilitary experiment was that the

informal or independent initiatives [e.g. in Palestine and in Malaya] raised the issue of control, unwittingly reinforcing wartime criticisms. This may have contributed, at least in part, to the decision to concentrate special operations within a formally-constituted regular regiment of the Army. ${ }^{18}$

Yet another significant difference between the U.S. and British paramilitary programs was that, while the former was constituted with an eye to countering external support for subversive activities in the context of an internal security assistance program - and by implication to hit the enemy on his own turf without having to assume responsibility for what could be construed by the other side as an act of war - the British program built on a long-standing military tradition of dealing with local rebellions in the British Empire, and hence was highly specialized. Consequently, the British Special Air Service (SAS), founded in 1950, left its mark on the age of decolonization as a highly effective counter-insurgency tool. As a result of this development, British counter-terrorism operations to this day are assigned to the Counter-Revolutionary Wing of the SAS regiment, and thus are handled by the military, not the police. The British choice of a military response to terrorism is therefore just as much a product of historical development (including relatively harmonious civil-military relations after

17 Berger, "Use of Covert Paramilitary Activity," 23-24.

18 David A. Charters, "From Palestine to Northern Ireland: British Adaptation to Low-Intensity Operations," in Armies in Low-Intensity Conflict. A Comparative Analysis, ed. David Charters and Maurice Tugwell (London: Brassey's Defence Publishers Ltd., 1989), 209. For an excellent account of the SAS in Malaya, see Peter Dickens, SAS. Secret War in South-East Asia. 22 Special Air Service Regiment in the Borneo Campaign, 1963-1966 (London: Greenhill Books, 2003; first pub. 1983). 
1689 ) as the refusal of a majority of European states to contemplate military options is the result of their own respective past experiences.

\section{Third-Force Paramilitary Options Against Terrorism: Four European Examples}

France, Italy, Spain and, later, Germany have all adopted paramilitary counter-terrorism solutions because of their respective historical experiences, which at one time or another brought their professional armies face to face with policing duties, exposed their inherent weaknesses in dealing with this task, and-from the eighteenth century onwards - highlighted the need for a military-strength or equivalent constabulary force to combat banditry and nip rebellion in the bud.

\section{The Italian Case: The Carabinieri}

Probably the best-known example of a paramilitary formation in the service of an early modern European state is the Italian corps of the Carabinieri. Also known as La Benemerita (the well-deserving), the Carabinieri can look back upon an exemplary service record and a rich history, tracing their origins to the volunteer Dragoni di Sardegna, first embodied in $1726 .{ }^{19}$ Functionally, the Carabinieri are part and parcel of the Italian Department of Defense; administratively, the corps is subordinated to the Italian Ministry of Internal Affairs. ${ }^{20}$ As we will see, this bipartite membership of the Italian paramilitary force in both civil and military government organizations is a pattern replicated in the French and Spanish cases (but not in the German).

The Carabinieri are an organization with policing duties distinct from the regular police (Polizia di Prevenzione), and were only recently formally absorbed into the Italian armed forces, not unlike the army, air force, and navy. Counter-terrorism falls into the bailiwick of both the regular police and the Carabinieri, but it is the Carabinieri who (until 1998) had the lead in counter-terrorism investigations: they currently exercise more of a coordinating role in the course of investigations, although they do retain a critically important role in live operations. On the operational level, the Carabinieri established a special force for deployment in counter-terrorism operations in December 1990, the Raggruppamento Operativo Speciale (ROS). ${ }^{21}$ The ROS is recognized as a highly competent special operations paramilitary. Notably, the advantage that the ROS holds over its equivalent in the regular police, the Nucleo Operativo Centrale di Sicurezza, is that the ROS is reasonably interoperable with units in the armed forces, an ability that arguably provides it with potential access to assistance services otherwise only available through the branches of the armed service, such as strategic air support for operations in dynamic environments.

19 See http://en.wikipedia.org/wiki/Carabinieri, accessed on 1 April 2004.

20 See www.carabinieri.it/Multilingua/ENG_P24-24_Governing_Bodies.htm, accessed on 13 May 2004.

21 Giuseppe de Lutiis, "Terrorism in Italy: Receding and Emerging Issues," in Confronting Terrorism. European Experiences, Threat Perceptions and Policies, ed. Marianne van Leeuwen (The Hague: Kluwer Law International, 2003), 102-103. 


\section{The Spanish Case: The Guardia Civil}

Following the death of General Francisco Franco in late 1975, the fledgling Spanish democracy was beset by a number of grave problems left over from the era of the Fascist state, not the least of which was separatist and ideologically motivated political violence. Another legacy of the Franco era was the existence of two militarized internal security organizations: the Policia Nacional and the Guardia Civil. In fact, regular army units patrolled the proverbial Spanish hotbed of separatist violence, the Basque Provinces, until 1981, when they were replaced by units of the Guardia Civil. ${ }^{22}$ Established in 1844, the Guardia Civil was originally modeled on the French Gendarmerie, which at least in part explains its paramilitary nature. It was reconstituted in 1940, whence it derives its current profile. ${ }^{23}$ For all intents and purposes, the Guardia Civil has retained its military character through the democratization process that has been underway in Spain since 1982. As a Gendarmerie-like paramilitary force, the Guardia Civil's duties are the policing of rural areas and the maintenance of the peace in urban communities of less than 20,000 inhabitants; they are also responsible for patrolling highways and for protection of critical government premises in the capital. ${ }^{24}$

With the sea change in Spanish politics following the general elections of 1982, when the Socialists came to power in a climate of political restiveness, the role of the army in the maintenance of internal security was further circumscribed. The new Spanish Ministry of the Interior elected to formally demilitarize the state response to political violence movements, and hence to employ the Guardia Civil as its principal tool in the protracted fight against a resilient, even burgeoning, movement of internal terrorism. ${ }^{25}$ The main reasons for this shift favoring the Guardia Civil were, on the one hand, that they "are administratively part of the army, but are placed in the Ministry of the Interior chain of command for operational purposes" and, on the other, that there was "remarkable discipline already existing within that agency." ${ }^{26}$ Like other European paramilitary corps, the Guardia Civil had to develop a special branch in order to adequately address the challenge of terrorism; the distillation of the Guardia Civil's operational counter-terrorism competence is vested in its special-forces wing, the Grupos Antiterroristas Rural (GAR). Thus, not unlike the Italians, the Spanish have chosen a solution that is formally civilian and effectively military in terms of its training, organization, equipment, and outlook.

${ }^{22}$ Fernando Reinares, "Democratization and State Responses to Protracted Terrorism in Spain," in Confronting Terrorism, ed. van Leeuwen, 66.

23 Thorsten Stodiek, Internationale Polizei. Ein empirisch fundiertes Konzept der zivilen Konfliktbearbeitung (Baden-Baden: Nomos, 2004), 69.

24 Fernando Jimenez, "Spain: The Terrorist Challenge and the Government's Response," in Western Responses to Terrorism, ed. Alex P. Schmid and Ronald D. Crelinsten (London: Frank Cass, 1993), 126.

25 Ibid., p. 126.

${ }^{26}$ Ibid., p. 125; Reinares, "Democratization and State Responses," 66. 


\section{The French Case: The Gendarmes}

Historically, the French can be said to take pride of place among Europe's paramilitaries: the Gendarmes, literally "men-at-arms"-or, in their proper appellation, the "sergeants-at-arms" - served as the executive branch of the French medieval justice system under the grand seneschal of the realm. ${ }^{27}$ They were organized into brigades - that is, properly embodied as a formal military unit - as early as 1720 . Like the Italian and Spanish paramilitaries, the Gendarmerie's various roles, such as the policing of the countryside and small urban areas, derived from historical mandates, for example that of keeping the king's peace on French highways through the centuries. Following the Revolution, Napoleon Bonaparte wrote of the Gendarmerie: "C'est la manière la plus efficace de maintenir la tranquillité ... une surveillance moitié civile, moitié militaire, répandue sur toute la surface du pays qui donne les rapports les plus précis...."28

More recently, the French paramilitary also played a critical role in the gradual retreat of empire before and during the era of decolonization, with its members serving in Indochina and Algeria. Similar to its fellow European paramilitary organizations, the Gendarmerie - with its strong esprit de corps, military culture, and institutional experience in fighting threats to internal security (i.e., including Indochinese and Algerian) was a natural choice to take the front line in the fight against terrorism. The task of the French paramilitary is also impressive in terms of its breadth: criminal investigations, crowd control, the protection of critical infrastructures, and investigations concerning the military both inside and outside of France, and especially those relating to foreign interventions. Like the Italian Carabinieri and the Spanish Guardia Civil, the Gendarmerie is administratively a part of the armed forces but is effectively directed by the Ministry of the Interior.

Unlike the other two corps, however, the Gendarmerie is structurally congruent with the armed services branches in that it maintains its own aerial and maritime and other specialist branches. Furthermore, the contemporary Gendarmerie's nation-spanning network and specialist personnel enable it to procure vital logistical support, provide intelligence and operational security, and to field trained operational interdiction capabilities. ${ }^{29}$ As early as 1974 , the Gendarmerie created its own special operations group, the Groupe de sécurité et d'intervention de la gendarmerie nationale, in response to the terrorist attacks on the 1972 Olympics in Munich. Within this group, the Groupe d'intervention de la gendarmerie nationale (GIGN) was given the special task of disrupting terrorist attacks and resolving hijacking situations. The GIGN proved their mettle in the Djibouti bus affair (February 1976), drugging the hostages to clear a low-risk line of fire for their special weapons systems operators. ${ }^{30}$ Since then, events in

See http://www.defense.gouv.fr/Gendarmerie/index.html, accessed on 1 June 2004.

Ibid.

29 Nathalie Cettina, "The French Approach: Vigour and Vigilance," in Confronting Terrorism, ed. van Leeuwen, 81 .

30 See http://www.specwarnet.com/europe/gign.htm, accessed on 1 June 2004. 
France and attacks on French interests abroad have irrefutably proven the necessity for a well trained and adequately armed specialized counter-terrorism branch. ${ }^{31}$

\section{The German Case: The Bundesgrenzschutz}

The final of the four examples reviewed here is arguably the most instructive in relation to the development of third-force paramilitaries in the combating of terrorism. Against the backdrop of the murder of eleven Israeli athletes during the Olympic Games held in Munich in 1972, and the clear failure of the ordinary police in the face of aggressive terrorist action, the Federal Republic of Germany was faced with the problem of creating the capability to tackle similar problems in the future. Ironically, the greatest impediment to a more forceful operational counter-terrorism solution at the time was the constitutionally ensconced, rigid division between the German military and the police, known as the Trennungsgebot. In the case of Germany, the Trennungsgebot was the direct result of the widespread conflation of the police and the military in the Third Reich, a practice that was fostered by the Nazi regime. ${ }^{32}$

The dramatic events that took place in the Olympic village in front of running cameras, and subsequently at the Fürstenfeldbrück airport near Munich, created tremendous pressure to act proactively to halt future terrorist attacks. Circumstances also helped weaken the historical German post-war reticence regarding firm policies and government actions that might be interpreted as being militaristic. Caught between a disastrous police failure and the impossible prospect of a politically unfeasible military deployment, the then-minister of the interior, Hans-Dietrich Genscher, instructed the liaison officer of the Federal Border Protection Agency (Bundesgrenzschutz) in his ministry, Colonel Ulrich Wegener, to create a counter-terrorism force - but one that would be neither part of the police nor part of the military. ${ }^{33}$

Wegener was quick to realize the opportunity offered by the combination of civilian institutional and paramilitary advantages in the Bundesgrenzschutz. Founded in 1951, the Bundesgrenzschutz is essentially the Federal German police force. Originally, its principal task was to guard the $1300-\mathrm{km}$ border it shared with Soviet-occupied territory during the Cold War. After 1972, the mandate of the Bundesgrenzschutz was expanded to include that of supplying the security and intervention reserves for the police forces of the West German Bundesländer, or provinces. It was out of this mandate that the Bundesgrenzschutz derived its special operations function. ${ }^{34}$

31 Jeremy Shapiro and Bénédicte Suzan, "The French Experience of Counter-terrorism," Survival 45:1 (Spring 2003): 67-98.

32 For reference on the troubled relationship between the "Trennungsgebot" and current counter-terrorism efforts, see Sylvia-Yvonne Kaufmann, "Ein Orwellscher Ueberwachungsstaat darf in Europa nicht entstehen," PDS press release of 18 March 2004, available at http://www.linxxnet.de/aktuell/19-03-04_sicherheit-eu.htm, accessed on 3 June 2004.

$33 \mathrm{Cf}$. http://encyclopedia.thefreedictionary.com/Ulrich $\% 20 \mathrm{~K} \% 20$ Wegener, accessed on 1 June 2004.

34 Stodiek, Internationale Polizei, 64-65. 
What makes the example of the Bundesgrenzschutz so interesting with respect to the discussion about third-force options is its development and nature: in the early days of the Federal Republic of Germany, this unit, which predated the establishment of the regular Bundeswehr, was conceived of as the first step in the rearmament of the postwar West German state. From the inception of the Bundesgrenzschutz, its character and equipment (as opposed to its legal role and formal constitution) were that of a paramilitary. ${ }^{35}$ In particular, the Bundesgrenzschutz was originally far more heavily armed than the police, being able to field armored vehicles, while also permitted to deploy light ordnance, bear heavy small arms, as well as use hand grenades. Until 1994, members of the Bundesgrenzschutz were even accorded the legal status of a combatant. Being neither a constabulary police force in the traditional sense nor formally a military unit, the Bundesgrenzschutz - because it was by definition a civilian unitprovided Wegener with a politically acceptable tool to fight terrorism both on German soil and abroad that could also satisfy most contemporary force saturation requirements beneath the threshold of war.

At the time, Wegener went to great lengths in order to study with the two best military special operations forces - the British Special Air Service and the Israeli Sayeret Matkal - and to incorporate the lessons learned in the formation of a homegrown counter-terrorism unit fully embedded in the Bundesgrenzschutz. The Grenzschutzgruppe 9 (GSG-9) was founded on 17 April 1973, and ever since it has acquitted itself well with respect to operational efficiency and in satisfying political concerns relating to its paramilitary character. ${ }^{36}$ With GSG-9, the quandary of the Trennungsgebot, as well as the credibility problems that plagued the first option while rendering the second unacceptable in the context of a counter-terrorism mandate, was overcome by creating a third, civilian option imbued with many unique strengths that were otherwise the exclusive preserve of military organizations. The singular value of GSG-9's story, however, is that a precedent for a democratically acceptable (that is, non-military) and accountable domestic and external intervention force was set that has since served as a model for other states, and may yet convince many more countries of its applicability.

\section{Military, Police, and the Paramilitary - Third-Force Option Reviewed}

The history of paramilitary formations reviewed earlier and the four examples scrutinized above suggest that paramilitaries, because of their nature rather than in spite of it, offer great benefits as counter-terrorism intervention tools. This section will focus on some of the typical problems experienced by the police and the military in the line of duty, specifically those pertaining to counter-terrorism tasks, and will attempt to demonstrate how paramilitary third-force options can help overcome some of these difficulties by offering the best characteristics from both worlds.

35 Ibid., 66.

36 See http://encyclopedia.thefreedictionary.com/GSG-9, accessed on 1 June 2004. 


\section{The Constabularization of the Military vs. the Militarization of the Police}

Since the end of the Cold War, military organizations in the West and elsewhere have been on the lookout for new horizons and responsibilities. Initially, the sudden vacuum left by the absence of the bipolar global conflict led to questions about the purpose of maintaining armed forces establishments at Cold War levels in terms of manpower and armament. Since that time, several responses have emerged in the ongoing debate surrounding the appropriate uses of the armed forces, ranging from robust peace support operations (PSO), to stabilizing forces, to humanitarian intervention. Whatever tasks these labels seek to designate, the fact remains that military organizations in both the East and West since 1990 have had to face a host of new challenges, some of which have pushed them to their limits (and beyond). Among these newly encountered complex situations are those that require regular troops to assume policing duties, often in challenging and difficult circumstances. This constabularization of the military has forced significant changes on an organization geared toward the waging of war: the ability to win a war in the Clausewitzian sense is predicated upon an army's ability to unleash maximum violence - a concept that is diametrically opposed to the constabulary requirement of the use of minimum force. ${ }^{37}$

Essentially, as Karl Haltiner has so cogently argued, the argument put forth by Morris Janowitz in his seminal work The Professional Soldier for a military force "committed to the minimum use of force, and ... viable international relations, rather than victory," has been grossly misunderstood. ${ }^{38}$ For, as Haltiner is quick to point out, Janowitz' observation was not directed at a new kind of military organization, but instead described a novel applied ethics of soldiering. ${ }^{39}$ Considering the history, constitution, and organizational makeup of contemporary military organizations, and against the backdrop of their traditional propensity to use overwhelming force in the fulfillment of their duty, reeducating members of the armed forces to comply with such an ethic is a gargantuan task that, by way of comparison, would make the implementation of the Geneva Conventions pale into insignificance. Such a fundamental change will neither happen overnight nor succeed through anything less than deep-seated reforms aimed at the transformation of armies into something completely new, which may as a consequence also causally impact the military's structure and organization.

As a hierarchical, top-down organization, the army would have to espouse principles that are anathema to itself in order to empower regular combatants to individually act in accordance with a constabulary/stringent peace-keeping ethic, such as flat hierarchies and the devolution of decision-making responsibilities to subalterns and noncommissioned ranks, if not to ratings and privates. ${ }^{40}$ The short-term constabularization

37 Grant Wardlaw, Political Terrorism. Theory, Tactics, and Counter-Measures (Cambridge: Cambridge University Press, 1989), 90.

38

Quoted in Karl W. Haltiner, "Polizisten oder Soldaten? Organisatorische Dilemmata bei der Konstabularisierung des Militärs," Österreichische Militärische Zeitschrift 3 (2001): 29198; at 292.

Ibid., 292.

Ibid., 292-93. 
of the military, especially if viewed in the light of the challenges that have arisen in the context of the recent deployment in Bosnia and Kosovo, would therefore appear impractical. ${ }^{41}$ For reasons of constitutional propriety, and because of concerns relating to the preservation of civil liberties, this observation applies even more pertinently to internal policing duties by the military in liberal democracies - especially if the military in question is one's own.

Reinforcing the impracticability of Janowitz's model, Wardlaw maintains that "the police and the army have significantly different roles, functions, and philosophies, which enable them to perform in quite different spheres. It is argued that this division is functional and that dysfunction would arise if uncontrolled overlap developed between the two organizations." 42 This potential for dysfunction, however, also applies to the police, and thus the obverse side of the problem discussed above is the militarization of the police. Historically, militarized police forces have been put to dubious uses by still more questionable autocrats, for example, in the case of the Chinese People's Armed Police (PAP) that was responsible for crushing the pro-democracy movement in Tiananmen Square (4 June 1989). ${ }^{43}$ Arguments militating against the deployment of an overly powerful and heavily armed police for internal security duties abound, not least because they recall and appear to substantiate the prospect of the police state. In that sense, from the point of view of civil liberties, the militarization of the police is at least as problematic as the deployment of the military for internal security duties is controversial. But, to use Wilkinson's nomenclature, would the same be true of a carefully calibrated, implemented, and politically reviewed overlap of the police and the military for the express purpose of proactively fighting terrorism? (We may recall that the establishment of GSG-9 would meet these parameters.)

In between the typical problems encountered by the military and the police in the course of having to take on tasks for which they are organizationally unsuited, there is another insidious problem: both organizations (but predominantly the military) are prone to take recourse to contracted security assistance forces. ${ }^{44}$ The recent scandal in Iraq's Abu Ghraib prison, where civilian contractors with a paramilitary character abused prisoners alongside ordinary troops, bears out this point. For this reason, and for our purposes, it is unacceptable that a counter-terrorism paramilitary unit be established, maintained, and directed by any body other than a sovereign government.

41 The half-way constabularization of the military in Kosovo was not least the result of a lack of trained police in the province. Arguably, constabularizing a military force under situational pressures created by an absence of professional police is a recipe for disaster. See Linda D. Kozaryn, "NATO Chief Says More Police Vital in Kosovo," American Forces Information Service, 8 February 2000, available at http://www.dod.mil/cgi-bin/dlprint.cgi?http://www. dod.mil/news/Feb2000/n02082000_20002083.html, accessed on 8 June 2004. Wardlaw, Political Terrorism, 90; italics added. Scobell and Hammitt, "Goons, Gunmen, and Gendarmerie," 218.

Ariana Eunjung Cha and Renae Merle, "Line Increasingly Blurred Between Soldiers and Civilian Contractors," Washington Post, 13 May 2004; available at www.washingtonpost. com/ac2/wp-dyn/A22547-2004May12?language=printer, accessed on 13 May 2003. 
The primary argument advanced on behalf of the police is that, while the armed forces are an inappropriate tool for internal security missions, the police force is ideally equipped to discharge domestic security duties. It has been suggested that police forces, as opposed to their military cousins, are also better suited to keeping the peace and maintaining internal security because they are essentially a bottom-up organization. ${ }^{45}$ The police offers unique assets, such as legitimacy, community proximity due to organizational decentralization and the traditional respect accorded to its constabulary powers (not least those regarding investigation and arrest), and considerable institutional memory, which also brings the experience so vital in the context of an internal security portfolio, which is traditionally its preserve.

Under normal conditions - that is, where the police discharge duties that do not bring its members face to face with situations akin to warfare - this has become a proven truism. At the same time, the very strengths extolled above are at the core of police forces' inherent weakness when confronted with large-scale counter-terrorism operations. Tore Nyhamar has described a select number of dilemmas arising from the nature of police organizations involved in confronting serious terrorist challenges in the Norwegian context:

The Chief of Police on the nearest district on land has no qualifications to lead what will be a military operation... The military might be asked to carry out a highly dangerous and difficult operation under the leadership of someone who is not qualified... The Chief of Police will be the one responsible for the outcome of the situation, even though the leadership will inevitably drift back to the military, creating a fault line between authority and responsibility. ${ }^{46}$

Nyhamar's point can also be applied to many liberal democratic states besides Norway that share similar civil-military structures and relations. Moreover, according to Nyhamar, "inertia reigns because the police do not want to cede authority to the military, and the military does not want to discuss situations in which it might have to play a subordinate role to the police." ${ }^{, 47}$ At the end of the day, the intractable question of which organization is to take the operational (not to mention the overall) lead in the fight against terrorism is intricately linked to the pros and cons of police and military organizations with respect to their suitability to carry out counter-terrorism activity. The question is also played out against the backdrop of concerns within the liberal democratic state pertaining to civil liberties and political acceptability, and of concerns about the defense of the state relative to adequacy, doctrine/operational principles, and ethics or outlook. Neither option satisfies all requirements; both are possessed of unacceptable or problematic characteristics, while both also possess indispensable assets. In

45 Haltiner, "Polizisten oder Soldaten?" 292-93.

46 Tore Nyhamar, "Norwegian Counter-Terrorism Policy in a Changing International Security Environment," unpublished draft paper presented on the occasion of the First International Expert Conference on National Counter-Terrorism Policy, 24-26 March 2004, Center for Security Studies, Swiss Federal Institute of Technology, 18. Quotation by kind permission of the author. 
a comparable dead-end, one commentator noted that "[t]he suggestion is also being voiced that we should consider the establishment of a so-called 'third force' - a paramilitary organization which occupies the middle ground between police and army."

The Third-Force Option As a Viable Alternative to Police and Military Inadequacies in the Combating of Serious Terrorist Violence

Not surprisingly, the pragmatism inherent in the suggestion for a third-force option came to fruition in a country where push quite literally has come to shove. The fivedecades-long experience with low intensity conflict, protracted terrorist attacks by political violence movements, and-in the absence of a viable political solution in the foreseeable future - the ongoing process in verifying the best means to meet security challenges has compelled the state of Israel to innovate. Apart from the well-known British example of the SAS, the Israeli Sayeret Matkal units have become legendary for their secrecy and prowess, and for simply doing the impossible. The best-known example of an Israeli counter-terrorism operation is one that too many writers have spilled too much ink over: the raid on Entebbe on 27 June 1976.

Conversely, what has - and understandably so - not been broadly advertised are the failures of the Israeli counter-terrorism effort. For our present purpose, one in particular stands out: the Mahalot Massacre. On 15 May 1974, three heavily-armed men seized a school in northern Israel, trapping a few dozen teachers and pupils on the premises. Sayeret Matkal and Sayeret Golani, two Israeli Defense Forces (IDF) infantry special operations units specializing in long-range reconnaissance missions, were given the task of ending the hostage situation. The reason for the use of the two Sayerets at that time was simply that they represented Israel's highest standard of operational counter-terrorism expertise. In the course of events, a series of mistakes occurred that can arguably be attributed to the essentials of military training and its inappropriate application in a hostage crisis. The death toll was high: twenty-one children and four adults, at least two of whom were killed by friendly fire. ${ }^{49}$ This is not to say that military training cannot be put to good and proper use in a hostage situation or other civilian-type scenario, but rather that any counter-terrorism capability in such a context must of necessity meet the requirements of the situation. In this case, the capabilities required would have been the surgical-tactical set of skills germane to a "pure" counter-terrorism outfit, such as GSG-9 or SAS-CRW.

\section{Between Maximum Violence and Minimum Force: The Birth of Unit YAMAM}

Following the Mahalot debacle, the government formed the Horev Commission (named after General Amos Horev) to investigate the special forces' failure. The commission's report states that they discovered a number of serious deficiencies, starting with inadequate training and, worse, insufficient inter-unit coordination due to the clannish esprit de corps of the units involved that percolated down through the ranks. It

48 Wardlaw, Political Terrorism, 91.

49 See http://www.us-israel.org/jsource/Society_\&_Culture/special.html, accessed on 8 June 2004. 
was especially this last item that was responsible for considerable rivalry between the two units. ${ }^{50}$ Among the structural recommendations made by the Horev Commission was that the responsibility for domestic counter-terrorism be taken out of the hands of the IDF; it was to be passed on to the police and the frontier guards (MAGAV). ${ }^{51} \mathrm{On}$ 26 January 1975, the government passed its Resolution 411, which removed the responsibility for domestic counter-terrorism from the military to the civilian branch. According to one commentator, the rationale for the governmental decision to give MAGAV the lead role in domestic counter-terrorism efforts was that "it's a paramilitary, half-breed organization." 52 Furthermore, the "personnel are selected and delivered by the IDF, but its orders and chain of command are via the police. Since the future unit was to be [a] domestic civilian unit but with a strong military focus ..., it was placed under MAGAV." 53

The high standards to which Unit YAMAM, MAGAV's special counter-terrorism force, was trained did not prevent it from becoming involved, albeit only passively, in Israel's greatest hostage rescue failure ever, the so-called "Beach Road" incident, in the course of which thirty-five civilians were killed in action and two hijackers were apprehended alive. In this instance, as in later incidents, the circumstances surrounding the IDF's Sayeret forces' intervention in a domestic terrorist hostage situation after the Mahalot Massacre was highly controversial, and were again tied to pronounced interservice rivalries that permeate the Israeli security establishment. Unit YAMAM, however, did fully justify the faith placed in it by the advocates of a third-force option. In March 1988, armed men hijacked a bus near Dimona, the site of Israel's principal nuclear research facility; the commuter bus carried mostly married women and children. The "Mother Bus" incident, as it became known, has since become a benchmark for counter-terrorism hostage rescue missions. The balance sheet of the operation was three hijackers killed against three hostage fatalities as a result of hostile fire.

\section{Conclusion: The Shaping of a Counter-Terrorism Instrument}

How was such a dramatic improvement in performance possible? The explanation is quite simple. The YAMAM cadre was recruited straight from elite military and civilian organizations, such as Sayeret Golani (elite infantry special forces), Sayeret Duvdevan (IDF counter-terrorism specialist unit) and, rarely, from the "blue" police. As mentioned previously, and as was realized in the course of the Second World War, the politically advantageous distinctiveness of third-force options was vested in such units' recruiting of specialists across the board of extant security organizations and the recruits' civilian redeployment. ${ }^{54}$ Although it still does not appear to attract the cream of

50 The Israeli Special Forces Home Page, "Unit YAMAM," 4; available at www.isayeret.com/ units/civi/yamam/article.htm, accessed on 6 May 2004.

51 For the MAGAV, see http://www.fact-index.com $/ \mathrm{m} / \mathrm{ma} / \mathrm{magav} \cdot \mathrm{html}$, accessed on 8 June 2004.

52 "Unit YAMAM," 5.

53 Ibid., 5.

54 See Scobell and Hammitt, "Goons, Gunmen, and Gendarmerie." 
the IDF's crop, YAMAM's admissions policy was and remains based on individual merit and training; its commanders' challenge really is to render military and civilian counter-terrorism operators philosophically compatible and operationally and technically interoperable in order to harness the full spectrum of their respective assets. Moreover, the YAMAM operational profile is geared towards surgical operations in a predominantly static environment (e.g., bus takeover, house entry and seizure), which can be likened to classical police operations, and contrasted with complex, dynamic special operations deep behind enemy lines (e.g., independent counter-insurgency missions with limited or no resupply). ${ }^{55}$

This mandated profile has permitted YAMAM from the outset to hone its skills to perfection for use in the domestic counter-terrorism context; arguably, within the confines of their purview they are almost without peer. At the same time, Unit YAMAM is no glorified police special weapons and tactics (SWAT) formation, as its members are much more likely to be experienced military special forces operators, and their equipment, not unlike that of the GSG-9, is frequently military-grade and thus considerably heavier than that used by the police. Nevertheless, its personnel base and high concentration of know-how has also given Unit YAMAM the ability to operate in more dynamic, war-like situations, such as in border security counter-terrorism missions, for example against infiltrators.

The bottom line is that, given the opportunity, the Israeli government realized the insufficiency of a purely military solution for combating incidents requiring a high degree of precision and extra circumspection due to the frequently acute potential for collateral damage. From the very beginning, Unit YAMAM was an experiment, wedding together disparate forces, commanded in the field by military ranks but fully under a civilian chain of command. Achieving the full integration of military and civilian combat capabilities and the optimal fusion of military and police special operations command structures was never without its problems, but it was certainly worth it. Despite the deeply entrenched tradition of the IDF as the principal force provider in cases of serious terrorist violence, the Israeli authorities grasped that something elsesomething new-was needed to meet the challenge of terrorist attacks inside the country's borders. Even beyond the national borders, the finely honed skills and pinpoint accuracy of a civilian paramilitary third-force option was, whenever required by the reality on the ground, to be preferred over the harder punch and superior pull of a classical military special forces capability.

All of these critical services could be provided by an optimum combination of civilian and military special operations cultures, bringing together a diverse knowledge base and, not least, instilling the necessity of using an adequate - even a minimumamount of force, but always with the ultima ratio option of massive force escalation. The probability that future terrorist violence will remain in the median range (e.g., heavy small arms and explosives) - which frequently falls between the force saturation levels of the military and the police-renders the consideration of a third-force option,

55 “Unit YAMAM," 11. 
THE QUARTERLY JOURNAL

with its civilian mandate and specialist knowledge, the best operational (and most politically viable) model for a democratically controllable, accountable, and acceptable counter-terrorism tool. 


\section{Bibliography}

Beckett, Ian F. W.. Modern Insurgencies and Counter-Insurgencies. Guerrillas and their Opponents since 1750. London: Routledge, 2001.

Berger, Major D. H.. The Use of Covert Paramilitary Activity as a Policy Tool: An Analysis of Operations Conducted by the United States Central Intelligence Agency, 1949-1951., 2004.

Cha, Ariana Eunjung, and Renae Merle. "Line Increasingly Blurred Between Soldiers and Civil-ian Contractors." Washington Post (2004).

Charters, David A.. "From Palestine to Northern Ireland: British Adaptation to LowIntensity Operations." In Armies in Low-Intensity Conflict. A Comparative Analysis. London: Brassey’s Defence Publishers Ltd, 1989.

de Lutiis, Giuseppe. "Terrorism in Italy: Receding and Emerging ." In IssuesConfronting Terrorism. European Experiences, Threat Perceptions and Policies. The Hague: Kluwer Law International, 2003.

Haltiner, Karl W.. "Polizisten oder Soldaten? Organisatorische Dilemmata bei der Konstabularisierung des Militärs." Österreichische Militärische Zeitschrift (2001).

J. Bell, Bowyer. The Secret Army: The IRA. New Brunswick, NJ: Transaction Publications, 1997.

Jimenez, Fernando. "Spain: The Terrorist Challenge and the Government's Response." In Western Responses to Terrorism. London: Frank Cass, 1993.

Kozaryn, Linda D.. "NATO Chief Says More Police Vital in Kosovo." American Forces Information Service (2000).

Rosenau, William. "The Eisenhower Administration, U.S. Foreign Internal Security Assistance, and the Struggle for the Developing World, 1954-1961," ." Low Intensity Conflict \& Law Enforcement 10, no. 3 (2001).

Russell, Peter E.. "Redcoats in the Wilderness: British Officers and Irregular Warfare in Europe and America, 1740 to 1760." William and Mary Quarterly 35, no. 4 (1978).

Scobell, Andrew, and Brad Hammitt. "Goons, Gunmen, and Gendarmerie: Toward A Reconceptualization of Paramilitary Formations." Journal of Political and Military Sociology 26, no. 2 (1998): 213-27.

Shapiro, Jeremy, and Bénédicte Suzan. "The French Experience of Counter-terrorism." Survival 45, no. 1 (2003).

Wardlaw, Grant. Political Terrorism. Theory, Tactics, and Counter-Measures. Cambridge: Cambridge University Press, 1989.

Wenger, Andreas, and Doron Zimmermann. International Relations. From the Cold War to the Globalized World . Boulder, CO: Lynne Rien, 2003. 
Wilkinson, Paul. Terrorism Versus Democracy. The Liberal State Response. London: Frank Cass, 2002.

Zwick, Edward. The Siege. Los Angeles: 20th Century Fox, 1992. 